\title{
Improved Oil Recovery of High-Viscosity Oil Pools with Physicochemical Methods and Thermal-Steam Treatments
}

\author{
L.K. Altunina* and V.A. Kuvshinov \\ Institute of Petroleum Chemistry SB RAS, Russia, 3, Academichesky Avenue, 634021, Tomsk - Russia \\ e-mail: alk@ipc.tsc.ru -vak@ipc.tsc.ru \\ * Corresponding author
}

\begin{abstract}
Résumé - Accroissement de la récupération des gisements d'huiles très visqueuses par méthodes physico-chimiques et injection de vapeur - L'Institut de Chimie du Pétrole de la Division Sibérienne de l'Académie des Sciences de Russie (ICP DS ASR) a développé de nouvelles méthodes physicochimiques pour accroître la récupération des gisements d'huiles très visqueuses produits par injection continue ou cyclique de vapeur d'eau. Cet article présente les résultats d'expériences réalisées au laboratoire et de tests pilotes réalisés sur le terrain en Russie et en Chine. D'une part l'utilisation de gels thermotropiques (inorganiques et polymériques) conduit à un accroissement du volume balayé par la vapeur injectée, à la diminution entre 3 et $45 \%$ de la production d'eau des puits producteurs, à l'augmentation des débits d'huile entre 11 et $33 \%$ et à la diminution des débits fluides entre 14 et $25 \%$. D'autre part, l'application de systèmes à base de surfactants qui peuvent générer du $\mathrm{CO}_{2}$ et une solution alkaline in situ, conduit à la diminution de la viscosité de l'huile dans un rapport 2 à 3 , à la diminution entre 10 et $20 \%$ de la production d'eau des puits producteurs, à l'augmentation des débits d'huile de $40 \%$ et à l'augmentation des débits fluides entre 5 et $10 \%$.
\end{abstract}

Abstract - Improved Oil Recovery of High-Viscosity Oil Pools with Physicochemical Methods and
Thermal-Steam Treatment - Novel physicochemical technologies have been developed at IPC SB RAS
to improve oil recovery from high-viscosity oil pools using thermal-steam and cyclic-steam treatments.
The results of laboratory investigations and pilot tests carried out in oil fields of Russia and China are
presented. The use of thermotropic inorganic and polymer gels increases coverage by steam injection,
decreases water cut of the production well by 3-45\%, increases the oil production rate by $11-33 \%$ and
decreases the fluid production rate by $14-25 \%$. Surfactant-based systems, generating $\mathrm{CO}_{2}$ and alkaline
buffer solution in situ, decrease oil viscosity 2-3 times and water cut of the production well by $10-20 \%$
and thereby increase the oil production rate by $40 \%$ and the fluid production rate by 5-10\%. 


\section{INTRODUCTION}

The quota of high-viscosity oil in total worldwide oil production is constantly growing. Large reserves of high-viscosity oils are found in Canada, Venezuela, Mexico, the USA, Russia, Kuwait and China [1].

Thermal-steam treatment of the oil pool by means of stationary or cyclic steam injections is considered as the most effective among all current methods used to produce high-viscosity oil [2-7]. Usually the temperature of the injected steam at the wellhead ranges from 310 to $320^{\circ} \mathrm{C}$ and its dryness is $70-80 \%$. As a rule, the injection pressure does not exceed 15-18 MPa. Combustion of 1 ton of oil in a steam generator yields from 10 to 15 tons of steam. The treatments are considered effective if 1 extra ton of oil is recovered per 3-4 tons of the injected steam. In cyclicsteam treatment the first cycle is the most effective and the efficiency of the following cycles decreases. However, the problem consists of low coverage by steam injection and decreased efficiency of thermal-steam treatment at a later stage of oil field development.

It is possible to improve the efficiency of thermal-steam treatment by combining it with physicochemical methods involving gel-forming and oil-displacing systems. Gels increase conformance with steam injection, while oil-displacing systems provide additional oil displacement. The development of complex methods combining thermal-steam and physicochemical treatments is at the initial stage. The number of such projects is rather small, though they are of great interest.

At present, novel technologies are being developed at the Institute of Petroleum Chemistry SB RAS (IPC SB RAS) to enhance oil recovery of high-viscosity oil pools. To increase the efficiency of thermal-steam and cyclic-steam treatments of high-viscosity oil pools we proposed combining them with physicochemical methods using thermotropic inorganic and polymer gels to regulate filtration flows and reduce water production and surfactant-based systems, which in thermal treatment are capable of generating carbon dioxide gas and alkaline buffer solution. As a result, they decrease oil viscosity and increase the oil displacement factor.

\section{GEL TECHNOLOGIES FOR IOR AND WATER SHUTOFF}

IOR technologies have been developed to regulate filtration flows in thermal-steam treatment and for water shutoff in cyclic-steam treatment with thermotropic gel-forming systems: polymer systems based on cellulose ether and inorganic systems, i.e. aluminum salt - carbamide - surfactant - water.

For some years physicochemical and hydrodynamic aspects of intra-reservoir generation of gels have been studied at the Institute of Petroleum Chemistry SB RAS [8-14].
Under surface conditions thermotropic gel-forming systems are low-viscosity aqueous solutions, which under reservoir conditions are converted into gels. Gelation proceeds due to the thermal energy of the reservoir or that of the injected heat carrier. The kinetics of gelation as well as the rheological and filtration properties of gels have been studied. As a result, we proposed gel-forming systems with different times of gelation, i.e. from several minutes to some days at temperatures ranging from 30 to $320^{\circ} \mathrm{C}$. Using such gel-forming systems one can create deflecting screens in a reservoir and regulate filtration flows, and thereby enhance oil recovery and decrease water cut of well production.

Five IOR technologies have been developed to enhance oil recovery from highly heterogeneous reservoirs, which are commercially produced in oil fields of West Siberia and Komi Republic [5-11]. The technologies are environmentally safe and economically effective. In 5 years 1.5 million tons of oil were recovered in the oil fields of West Siberia due to application of gel technologies developed at IPC SB RAS. In recent years novel complex technologies have been developed to improve oil recovery from high-viscosity oil pools. Thermotropic inorganic and polymer gels have been used in thermal-steam and cyclic-steam treatments, intended to regulate filtration flows and to decrease water production in oil fields of Russia and China.

\subsection{Water Shutoff Technology Employing Inorganic Gels}

IOR technologies involving inorganic gel-forming systems are effective at increasing conformance in water or steam injections in the temperature range of $40-320^{\circ} \mathrm{C}$. One uses the ability of the system aluminium salt - carbamide - water - surfactants to generate inorganic gel and $\mathrm{CO}_{2}$ in situ [5-9]. A homogeneous solution containing a gel-forming system is injected into a reservoir. Due to the thermal energy of the reservoir or that of the injected heat carrier carbamide is subjected to hydrolysis to yield $\mathrm{CO}_{2}$ and ammonia, the $\mathrm{pH}$ of the solution increases and aluminum ions are hydrolyzed. As a result, within a certain time the whole solution is practically immediately converted into gel, Figures 1, 2. Gelation decreases reservoir permeability to water. A degree of permeability decrease is proportional to the initial water saturation and reservoir rock permeability to water. The static shear stress of the gel ranges from 3 to $40 \mathrm{~Pa}$.

A principle of intra-reservoir gelation was used to create the gel-forming systems GALKA and GALKA-surfactants. In 1996 IPC SB RAS in association with the stock company "Nefteotdacha" organized commercial production of the liquid GALKA system using alumina-containing industrial waste. In 2000 IPC SB RAS in association with the stock company "AURAT" organized the commercial production of the following solid GALKA systems: GALKA-thermogel-C for reservoir temperatures ranging from 70 to $320^{\circ} \mathrm{C}$, 


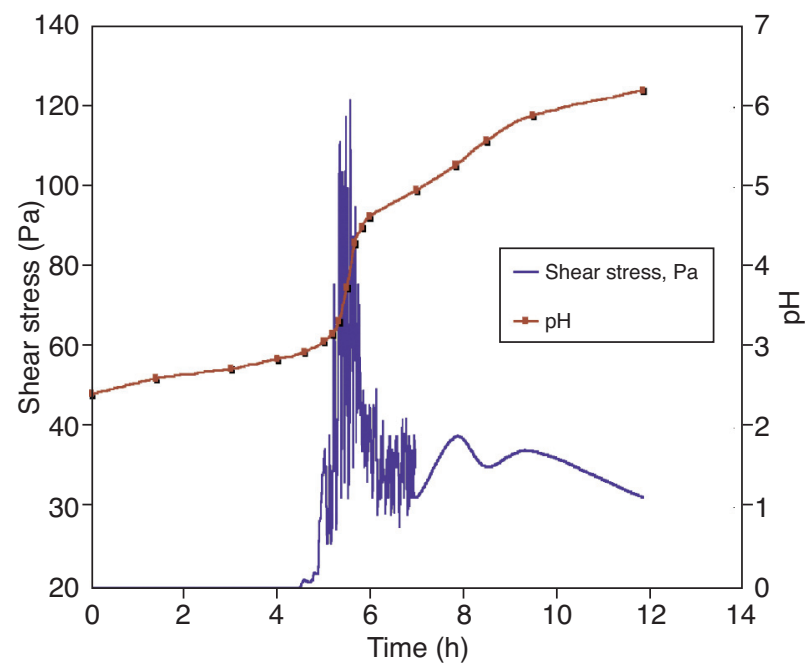

Figure 1

Shear stress and $\mathrm{pH}$ changes in the system ammonium salt carbamide - water at gelation during thermostating at $97^{\circ} \mathrm{C}$.

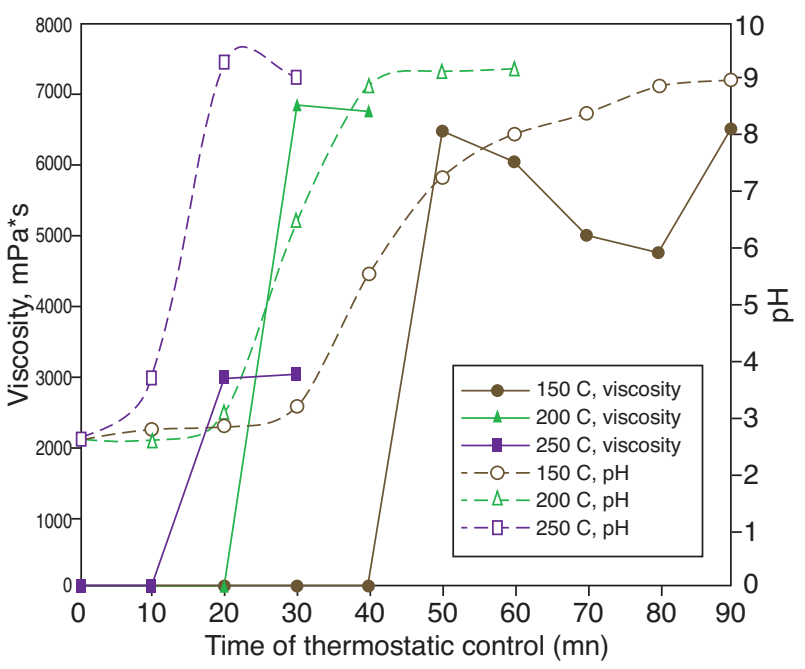

Figure 2

Viscosity and $\mathrm{pH}$ changes in the system ammonium salt carbamide - water at gelation during thermostating at 150$250^{\circ} \mathrm{C}$.
GALKA-thermogel-U for reservoir temperatures ranging from 40 to $70^{\circ} \mathrm{C}$, and GALKA-thermogel-NT for reservoir temperatures ranging from 20 to $40^{\circ} \mathrm{C}$. Regulated temperature of gelation, homogeneity and low viscosity of aqueous solutions, solid commercial form and low freezing-points of the solutions are the main distinctive features of GALKAthermogel systems. Therefore, one can use GALKA systems: - in a wide temperature range $\left(20-320^{\circ} \mathrm{C}\right)$, including thermalsteam treatment of reservoirs;

- for low-permeable reservoirs;

- to inject into a well by dosing directly into a conduit without preliminary dilution;

- under winter conditions.

Due to the unique capacity of inorganic GALKA gels to withstand temperatures up to $300-320^{\circ} \mathrm{C}$ they were used to increase coverage by thermal-steam treatment at the development of high-viscosity oil pools [8, 9]. In 2002 the stock company "LUKOIL-Komi" carried out pilot tests in the test area PTV-3, Figure 3. They used the solid commercial form of the GALKA-thermogel-C system for thermal-steam stimulation of a Permocarbonic pool in Usinskoye oil field. Trace-indicators were injected before and after gel-forming solution injections.

Tracing demonstrated the hydrodynamic connection of all three development objects: lower, middle and upper in the pool section within the bounds of the test area. In 2002 the GALKA-thermogel-C system was injected into steam-injection wells: $4254\left(106 \mathrm{~m}^{3}\right), 4242\left(80 \mathrm{~m}^{3}\right), 4253$ and 4264 $\left(200 \mathrm{~m}^{3}\right)$. Gelation in the buttonhole zone was determined by the pressure increase in the process of gel-forming solution injection and by decreased injectivity of the wells after the injection. Thus, before the injection the injectivity of wells 4254 and 4242 was $960 \mathrm{~m}^{3} /$ day at the injection pressure $P_{3}=0 \mathrm{~atm}$, while after the injection the injectivity of well

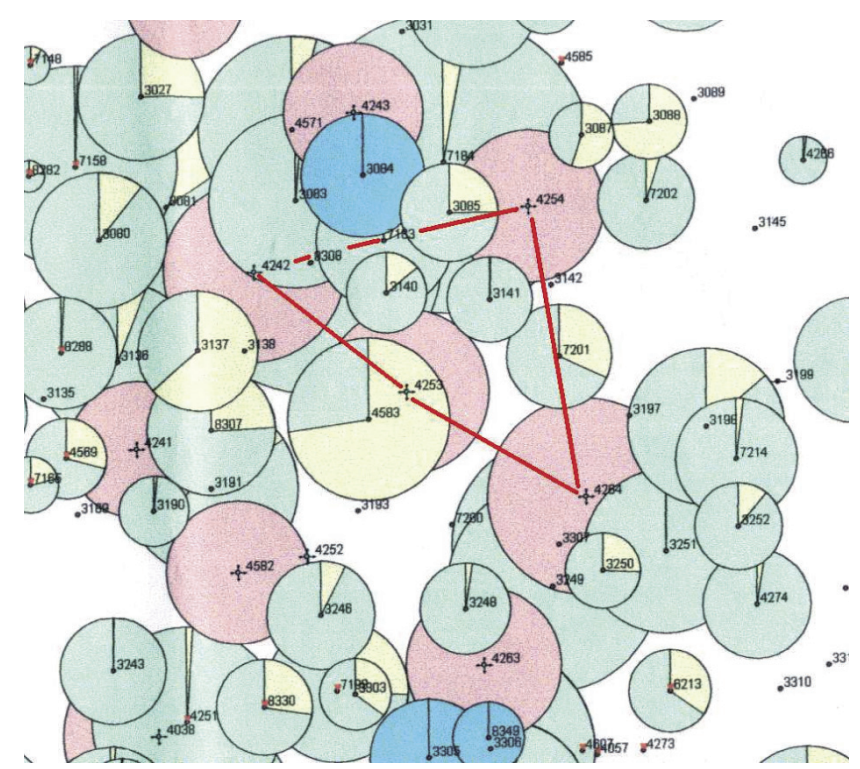

Figure 3

Scheme of PTV-3 test area in Usinskoye oil field (middle object) for injection of GALKA-thermogel-C into steam injection wells 4242, 4253, 4254 and 4264. 


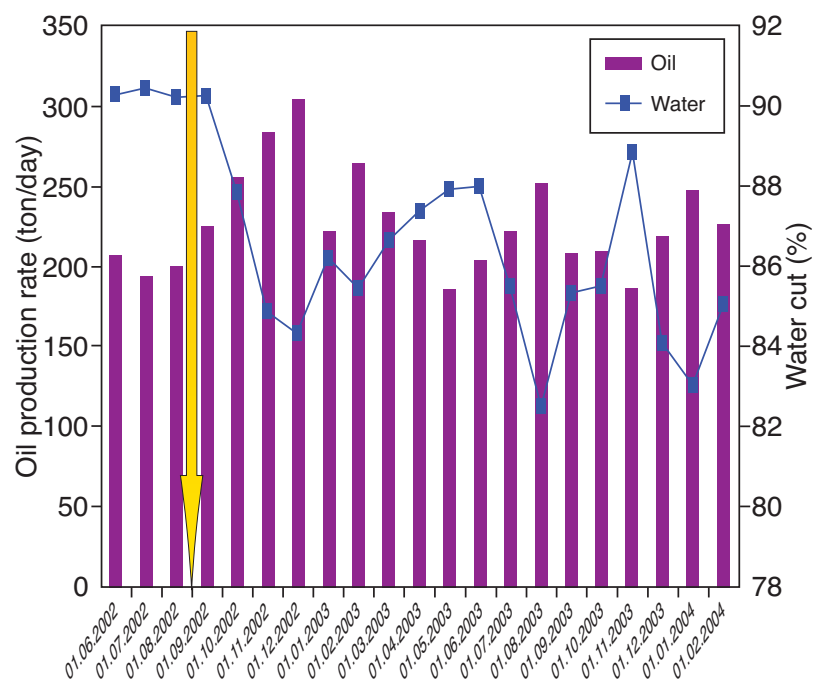

Figure 4

Dynamics of water cut and monthly oil production from June 2002 to February 2004 for 29 wells in the test area of GALKA-thermogel-C injection in usinskoye oil field.

4254 became $500 \mathrm{~m}^{3} /$ day at $P_{3}=50 \mathrm{~atm}$, and that of well $4242-250 \mathrm{~m}^{3} /$ day at $P_{3}=20 \mathrm{~atm}$. The solid commercial form of the GALKA-thermogel-C system proved to have high technological effectiveness and absolute environmental safety under the reported conditions. By the characteristics of oil displacement based on the field data obtained for 29 production wells located in the test area we estimated the volume of the additionally recovered oil. In the period from October 2002 to February 2004 one recovered in addition 33 thousand tons of oil. The technological effectiveness amounts to 275 tons of extra recovered oil per 1 ton of solid commercial form of the GALKA-thermogel-C system. The production wells respond by decreased water cut by $3-45 \%$, an increased oil production rate, on average by $23 \%$ (Fig. 4) and a decreased monthly liquid production rate, on average by $19.8 \%$.

\subsection{Water Shutoff Technology Employing Thermotropic Polymer Gels}

A novel method has been developed at the Institute to enhance oil recovery from highly heterogeneous reservoirs via regulation of filtration flows and increased conformance with thermoreversible polymer gels $[6,7,10,11]$, which are formed from polymer solutions with lower critical solution temperature (LCST). Reservoir heat energy is a factor causing gelation. Conversion of low-viscosity solution into gel upon increase in temperature is a reversible phase transition. Cellulose ethers (CE) are the most promising polymers. In the temperature range of $20-120^{\circ} \mathrm{C}$ the dependence of $\mathrm{CE}$ solution viscosity has an extreme character - at first the heating decreases viscosity and then upon further heating the viscosity increases and the solution is converted into gel, Figure 5. In the interval from 40 to $120^{\circ} \mathrm{C}$ it is possible to regulate the time and temperature of gelation with inorganic and organic additions, adapting temperature and water salinity to concrete formation conditions. The action of electrolytes and non-electrolytes as additions is additive. The gels are stable at the temperatures up to $220^{\circ} \mathrm{C}$ and can be effectively used for water shutoff and also to prevent gas breakthrough and liquidate gas cones.

Based on the studies we have developed gel-forming METKA and ROMKA systems and the technologies employing these systems to increase conformance and for water shutoff $[7,10,11]$. In 1996-1997 large-scale pilot tests of EOR technologies were carried out in West Siberia. Since 1998 EOR technologies have been commercially employed in the oil company "LUKOIL". The stock company "OTO" has created a commercial movable installation to prepare and inject the systems. After the injection of the system one observed decreased water cut and an increased oil production rate in the production wells. During 1998-2003 the METKA system was injected into 382 wells and extra oil recovery amounted to 480 thousand tons. The period of payback is 5-9 months. The efficiency of the technology is on average about 1300 tons per one well treatment.

EOR technology has been developed to enhance oil recovery from high-viscosity oil pools. It is aimed at regulating filtration flows in thermal-steam treatment with the gels based on cellulose ethers. The systems, based on thermoreversible gel-forming polymer systems with LCST: cellulose ether aqueous phase, were proposed to increase the efficiency of cyclic-steam stimulation of high-viscosity oil pools. The studies on gelation kinetics and rheological characteristics of the systems at $20-250^{\circ} \mathrm{C}$ demonstrated that upon reaching gelation temperature (phase transition solution - gel) one can observe a practically momentary and reversible increase in shear stress and viscosity (from 8-30 to $100-90000 \mathrm{mPa} \cdot \mathrm{s}$ ): upon cooling the gel again converts into liquid. The rheological parameters of gels are reproduced in cyclic reversal of heating and cooling processes.

Rheological studies carried out using rotational viscometer Haake rheostress 600 at temperatures ranging from 20 to $150^{\circ} \mathrm{C}$ and pressure up to $50 \mathrm{~atm}$ demonstrated that the addition of carbamide and ammonium thiocyanate to $\mathrm{CE}$ solution increases gelation temperature, at the same time the action of addition agents is additive: upon simultaneous introduction of carbamide and ammonium thiocyanate the temperature of gelation may be higher than $100^{\circ} \mathrm{C}$ (Fig. 6). The gels are stable and preserve their rheological characteristics at high temperatures - up to $150-200^{\circ} \mathrm{C}$. In the region of shear rates $0.5-5 \mathrm{~s}^{-1}$ the gel is a solid-like body; the pattern of rheological dependencies indicates its viscoelastic 


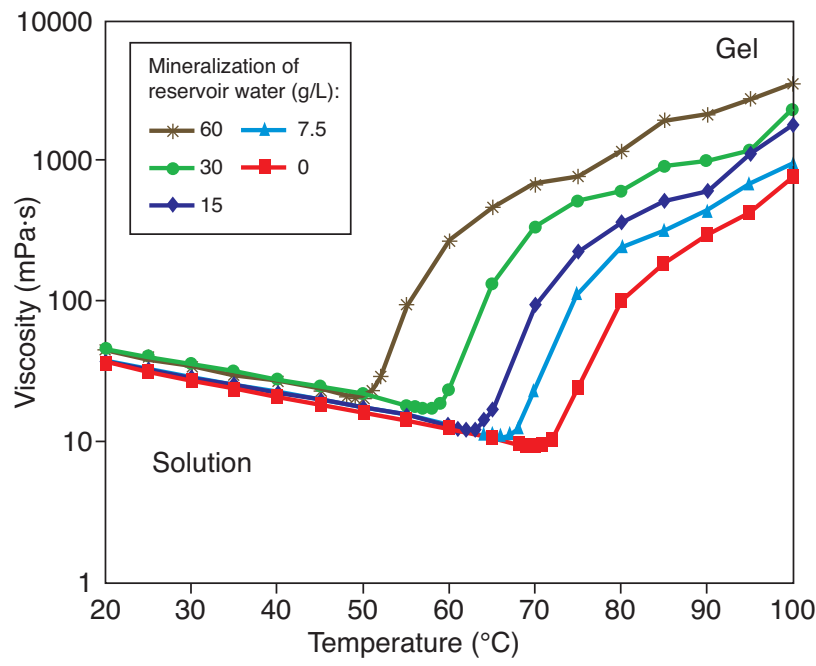

Figure 5

Temperature dependence of viscosity of $1 \%$ cellulose ethers in different formations of water salinity.

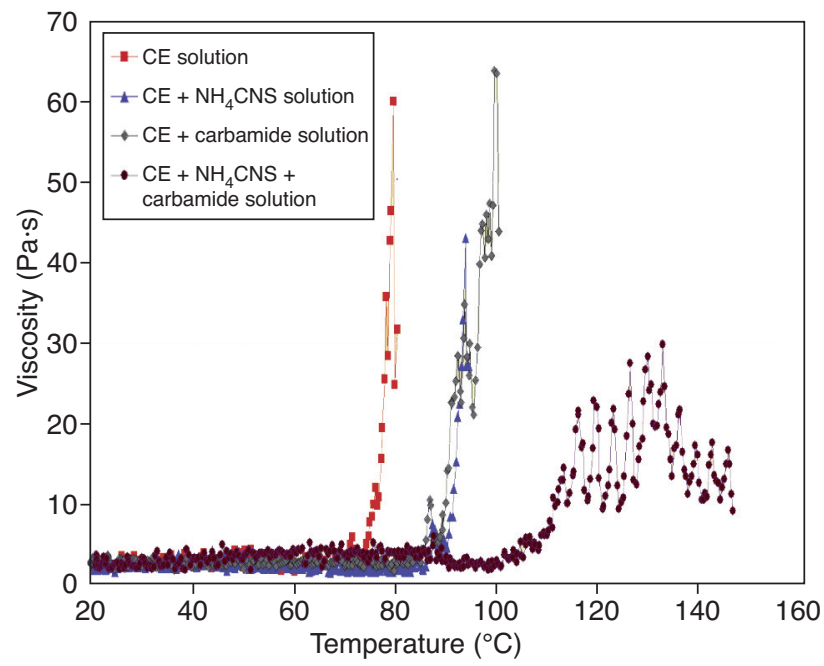

Figure 6

Viscosity change in phase transition solution - gel for polymer with LCST (cellulose ether). properties. Therefore, gel-forming systems can be used to regulate the steam injection profile in cyclic-steam wells.

The pressure gradient was studied upon filtration of water, oil and water again through solid water-saturated samples of sand rock containing residual oil and gel at $60^{\circ} \mathrm{C}$. The studies were carried out using the installation intended to study filtration at fixed discharge and back pressure of $20 \mathrm{~atm}$ though a reservoir model and consisted of one column with sand rock at initial rock permeability to gas $11 \mathrm{D}$. We used core samples recovered from reservoir rocks of the oil field, oil and formation water. One pore volume ( $1 V_{\text {Пор }}$ ) of the gel-forming system was filtered at room temperature through solid water-saturated rock samples containing residual oil at back pressure of $20 \mathrm{~atm}$. Then it was subjected to thermostating for 12 hours at $60^{\circ} \mathrm{C}$ followed by successive filtration of water, oil and water again at $60^{\circ} \mathrm{C}$. The results obtained are presented in Figure 7. Gelation in the formation rock causes selective decrease in the phase permeability of rock to water, Figure 7: pressure gradient upon water filtration through the gel is 2-3 times higher as compared with oil filtration.

Filtration characteristics and the oil displacement factor were studied in physicochemical treatment of a high-viscosity oil pool with a gel-forming system under reservoir-simulating conditions at $200^{\circ} \mathrm{C}$. The studies were carried out using the installation intended to study filtration at fixed discharge though a reservoir model and consisted of two parallel columns of different permeability, simulating a heteroge- neous reservoir. We used core samples recovered from reservoir rocks of oil fields, oils and formation waters.

It has been determined that application of a gel-forming system equalizes filtration flows due to decreased mobility in

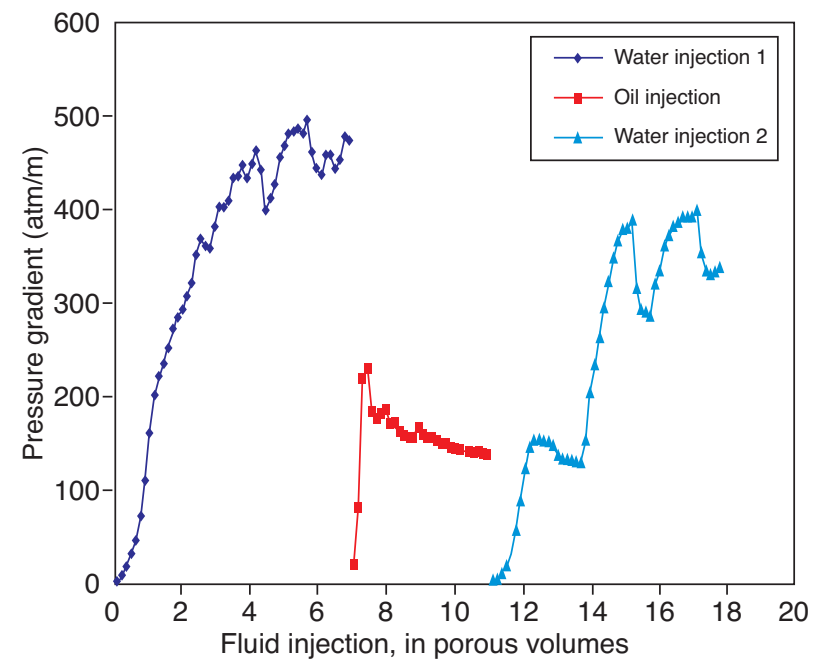

Figure 7

Selective increase in phase permeability of rock to water after $\mathrm{CE}$ gelation in reservoir rock. Filtration of water, oil and water again through sand rock with gel at $60^{\circ} \mathrm{C}$, at back pressure of $20 \mathrm{~atm}$; initial rock permeability to gas is $11 \mathrm{D}$. 


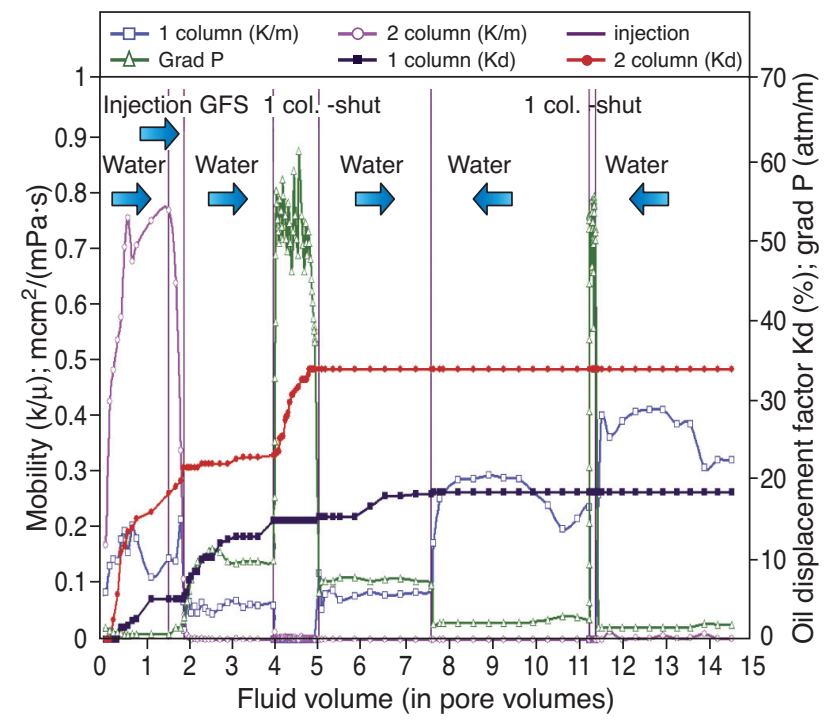

Figure 8

Rearrangement of filtration flows and after-washing of highviscosity oil from a reservoir model at $200^{\circ} \mathrm{C}$ under cyclic-steam simulating conditions after injection of a gel-forming system (GFS). Water injection is indicated with arrows. Permeability: 1st column $-0.397 \mu \mathrm{m}^{2}, 2$ d column $-2.123 \mu \mathrm{m}^{2}$.

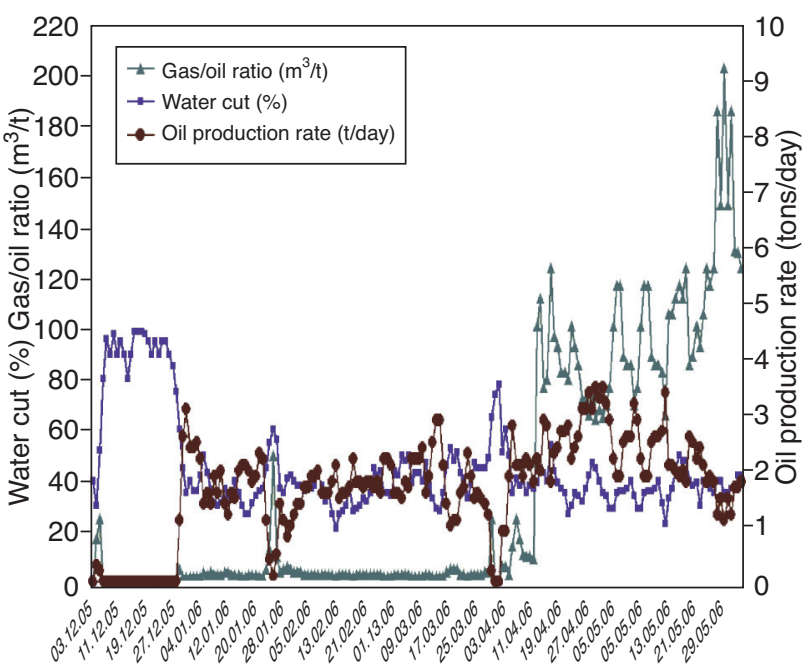

Figure 9

Operation characteristics of cyclic-steam well Gao3-6-0155, a high-viscosity oil pool in Gaosheng oil field, after METKA system and steam injections in November 2005. highly permeable seams, that is accompanied by oil afterwashing from both lower and highly permeable zones of a reservoir model. For example, injection of the gel-forming system into a heterogeneous reservoir model, where column permeability differed by 5.4 times $\left(0.397\right.$ and $\left.2.123 \mu \mathrm{m}^{2}\right)$, Figure 8, caused rearrangement of filtration flows; at the same time, the ratio of liquid mobility in the reservoir model varied from 1:4.3 to 50:1. Upon the reverse water pumping, simulating operation conditions of a cyclic-steam well, the filtration mode remained unchanged. As a result, the oil displacement factor increased by $12-13 \%$.

Gel-forming systems proved to have high efficiency for heterogeneous reservoir models with seam permeability differing by 3.4-5.4 times, and at $200^{\circ} \mathrm{C}$ one can observe: rearrangement of filtration flows and increased oil displacement factor. We can recommend regulating filtration flows of reservoir fluids, to decrease water cut, and to increase conformance by thermal-steam and cyclic-steam treatments of a high-viscosity oil pool both at early and later stages of oil field development.

The studies mentioned above served as the basis for designing pilot tests of a thermoreversible gel-forming system. In 2005-2006 such pilot tests were successfully carried out in Liaohe oil field. The gel-forming METKA system was tested to increase the efficiency of cyclic-steam treatment of a high-viscosity oil pool.
The rheological and filtration characteristics of the METKA system, based on commercial products from China, were studied. Laboratory research was carried out, and as a result the optimal composition was selected to carry out pilot tests in two wells in cyclic-steam treatment of a high-viscosity oil pool in Gaosheng oil field; the amount of reagents was calculated to carry out pilot tests in two wells; instructions on preparation and injection of the METKA system were developed.

In 2005-2006 the gel-forming METKA system was injected into two cyclic-steam wells in a high-viscosity oil pool in Gaosheng oil field, which is a part of Liaohe oil field. Side wells Gao3-6-0155 and Gao3-6-0163 are located in block Gao 3618 in the north of Gao 3 area in Gaosheng oil field, China. The Shahejie series of the Lianhua stratum is productive. Its structural trap is of a monocline type. There are 4, 5, 6 sand bodies in the pool. Average depth of productive formation is $1680 \mathrm{~m}$, sealed bed, without gas cap and bottom water. Formation area is $0.86 \mathrm{~km}^{2}$, geological reserves of oil amount to 10.623 million tons. Average formation thickness is $170 \mathrm{~m}$. In the porous fractured reservoir, average permeability is $450 \mathrm{mD}$, porosity amounts to $20 \%$. Initial formation pressure is $18.4 \mathrm{MPa}$, saturation pressure is $11.26 \mathrm{MPa}$ and current formation pressure is 2.01 MPa. Initial formation temperature is $57^{\circ} \mathrm{C}$. Average oil saturation amounts to $43.7 \%$. Oil viscosity in rock is $605 \mathrm{mPa} \cdot \mathrm{s}$. Oil density is $0.942 \mathrm{~g} / \mathrm{cm}^{3}$. Formation water 


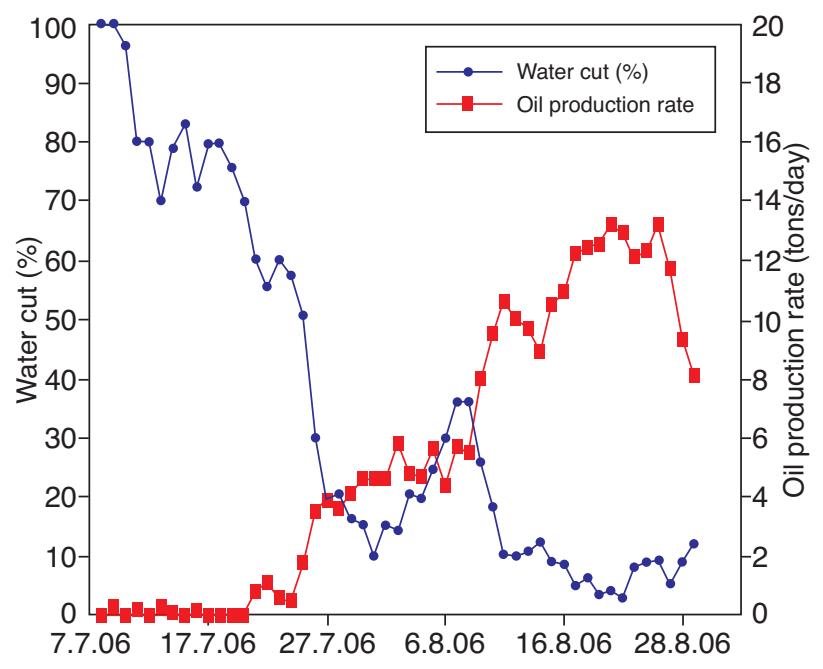

Figure 10

Operation characteristics of cyclic-steam well Gao3-6-0163, a high-viscosity oil pool in Gaosheng oil field, after METKA system and steam injections in June 2006.

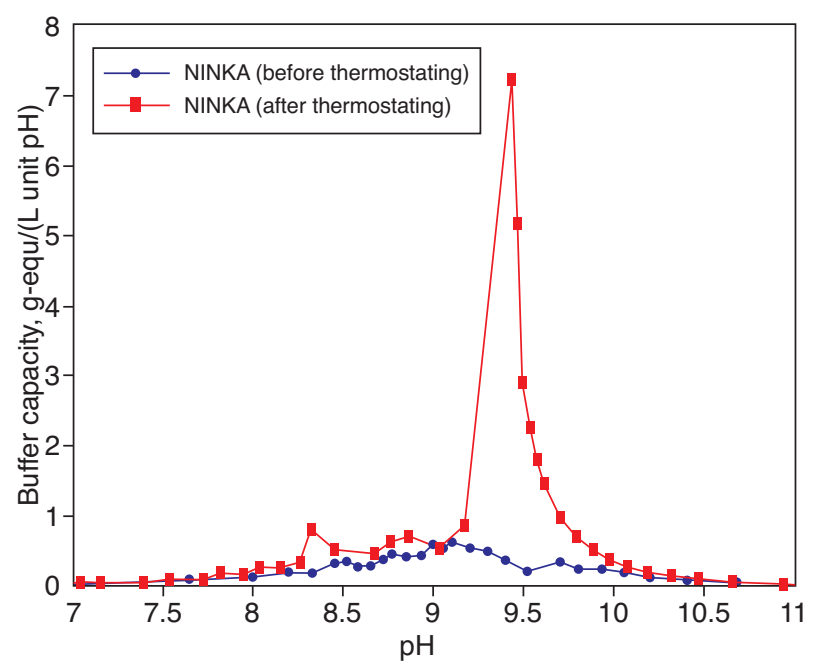

Figure 11

Generation of alkaline buffer solution due to system hydrolysis after thermostating for 9 days at $100^{\circ} \mathrm{C}$.

salinity is $3200-3620 \mathrm{mg} / \mathrm{L}$, total alkalinity is $26-28 \mathrm{mg} / \mathrm{L}$, total hardness is $24-39 \mathrm{mg} / \mathrm{L}$ and water type is $\mathrm{NaHCO}_{3}$.

In November 2005120 tons of the METKA system and 4400 tons of steam were injected into the cyclic-steam well Gao3-6-0155; in June 2006110 tons of the METKA system and 3900 tons of steam were injected into the well Gao3-60163 in Gaosheng oil field. The results of the injections are presented in Figures 9 and 10. The injection of the gel- forming system resulted in decreased water cut and an increased oil production rate. Gel technology employing the METKA system to enhance oil recovery is environmentally safe and economically effective.

Thus pilot tests proved the efficiency of gel technology in cyclic-steam and thermal-steam treatments. The thermotropic inorganic and polymer gels used in oil fields of Russia and China for regulation of filtration flows and water shutoff in high-viscosity oil pools increased coverage by steam injection, decreased water cut of well production by $3-45 \%$, increased the oil production rate by $11-33 \%$ and decreased the liquid production rate by $14-25 \%$.

\section{EOR OF HIGH-VISCOSITY OIL FIELDS BY SYSTEMS BASED ON SURFACTANTS, CAPABLE OF GENERATING $\mathrm{CO}_{2}$ AND ALKALINE BUFFER SOLUTIONS IN SITU}

\subsection{Physicochemical Basis for IOR Technology}

To increase the efficiency of oil recovery IOR technology has been developed, combining thermal-steam and physicochemical treatments of high-viscosity oil pools $[15,16]$. Surfactant-based systems (NINKA and IKhN-KA systems) were developed, which in thermal treatment are capable of generating carbon dioxide gas and alkaline buffer solution (Fig. 11). As a result, they decrease oil viscosity (Fig. 12) and increase the oil displacement factor [8, 16-18].

IOR technology is aimed at increasing current and final oil recovery factors due to decreased oil viscosity, increased conformance and decreased interfacial tension on the oil water - rock boundary, decreased swelling ability of the clay cements, improved wetting ability, increased mobility of reservoir fluids, increased oil recovery factor and decreased residual oil saturation.

According to IOR technology one injects the slug of aqueous solution of the NINKA system based on surfactant - carbamide - ammonium salt - water, which is capable of generating $\mathrm{CO}_{2}$ and ammonium buffer solution in situ (Fig. 11) due to the thermal energy of the injected heat carrier. Generated $\mathrm{CO}_{2}$ decreases oil viscosity (Fig. 12) and thereby causes favorable change in the proportion of oil and aqueous phase mobility.

The presence of carbon dioxide gas and ammonia in the water vapor facilitates the conservation of the vapor-gas mixture at the temperature below the temperature of vapor condensation and thereby increases the efficiency of the intrastratal migration of oil components via a distillation mechanism. Besides, carbon dioxide gas and ammonia decrease the swelling of clay minerals in a rock-reservoir and thereby preserve the initial permeability of the formation. An ammonium buffer system, formed at ammonia dissolution in an aqueous solution of ammonium salt, performs the same 

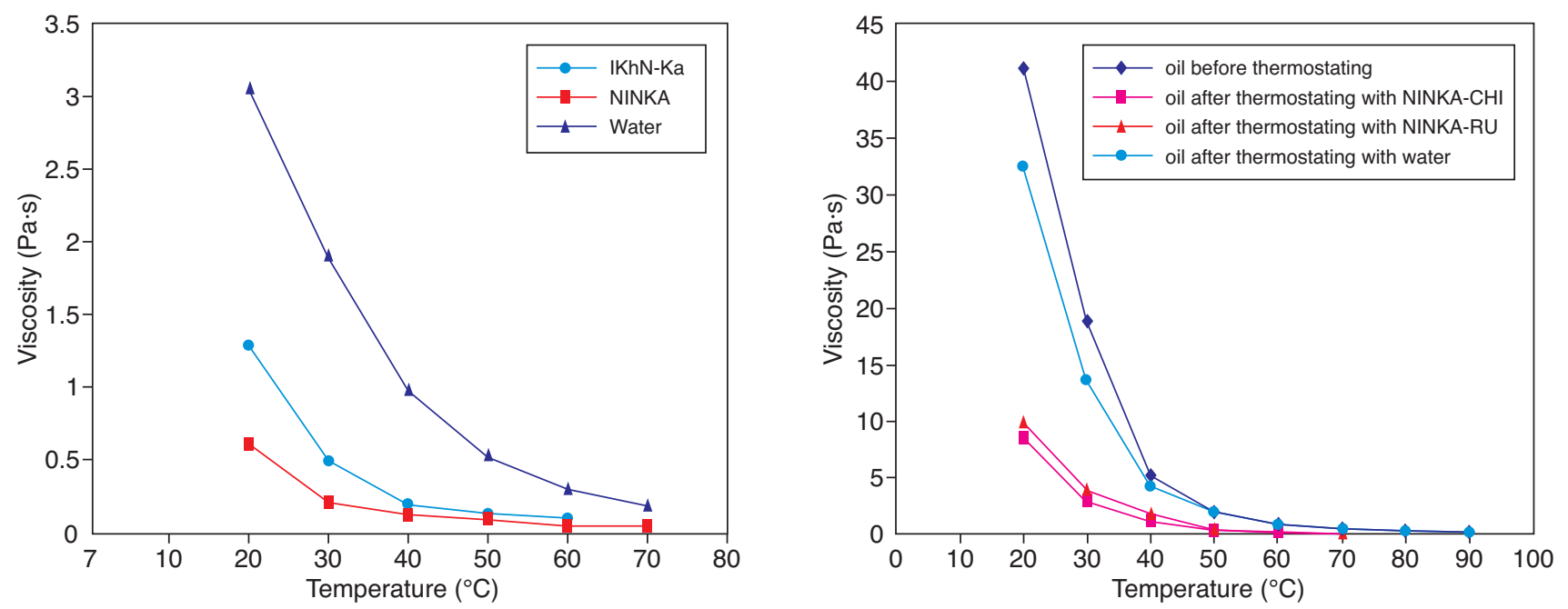

Figure 12

Decrease in oil viscosity, after thermostating for $6 \mathrm{~h}$ at $200^{\circ} \mathrm{C}$ with water and IKhN-KA and NINKA systems: (a) Usinskoye oil field (Russia), (b) Liaohe oil field (China).

function. Due to its alkalinity, $\mathrm{pH}=9-10$, and the presence of surfactants, it intensifies countercurrent soaking and oil displacement. The surfactants and alkaline buffer system promote destructuring and thinning of high-viscosity layers or films formed on oil - water - rock boundaries, which worsen fluid filtration in the reservoir and decrease oil recovery.

In oil displacement with a surfactant-based system the mobility of the filtrated fluid increases 1.5-6 times due to decreased viscosity and improved wetting ability; the oil displacement factor increases by $10-20 \%$ and the residual oil saturation noticeably decreases, providing stabilization or decrease in water cut of the production wells and thereby an enhancement in oil recovery. Ammonium salt composing the system is also a trace indicator. Under laboratory conditions using a high-pressure filtration device it has been determined the alteration of steam slugs and surfactant-based system increases the oil displacement factor as compared with thermal-stem treatment, Figure 13. The first injected slug of the system makes the major contribution to the increase in the oil displacement factor. A computer model of the technological process has been created.

\subsection{Pilot Tests of IOR Technology in Thermal-steam Treatment in Usinskoye Oil Field, Russia}

Pilot tests of IOR technology employing the NINKA system were carried out to improve the efficiency of thermalsteam treatment in the test area PTV-3 of a Permocarbonic reservoir of a high-viscosity pool in Usinskoye oil field. In
$2002264 \mathrm{~m}^{3}$ of the NINKA system were injected into steam-injection wells 4029,4040 and 4596 . We injected $88 \mathrm{~m}^{3}$ of $50 \%$ solution of the NINKA system into each well. Before the injection the wells had high injectivity

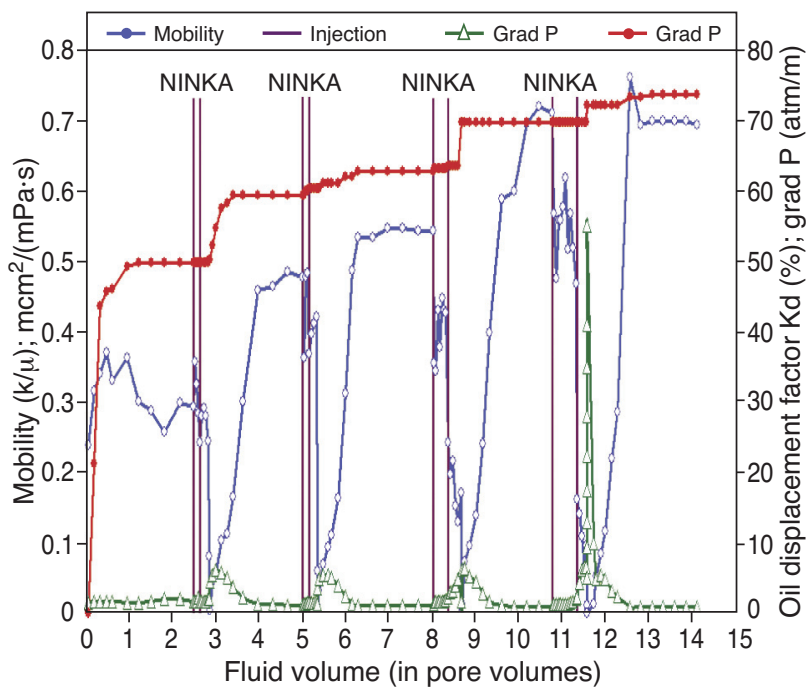

Figure 13

Increase in the oil displacement factor due to alternate filtration of steam and slugs of the surfactant-based system generating $\mathrm{CO}_{2}$ and alkaline buffer solution. 

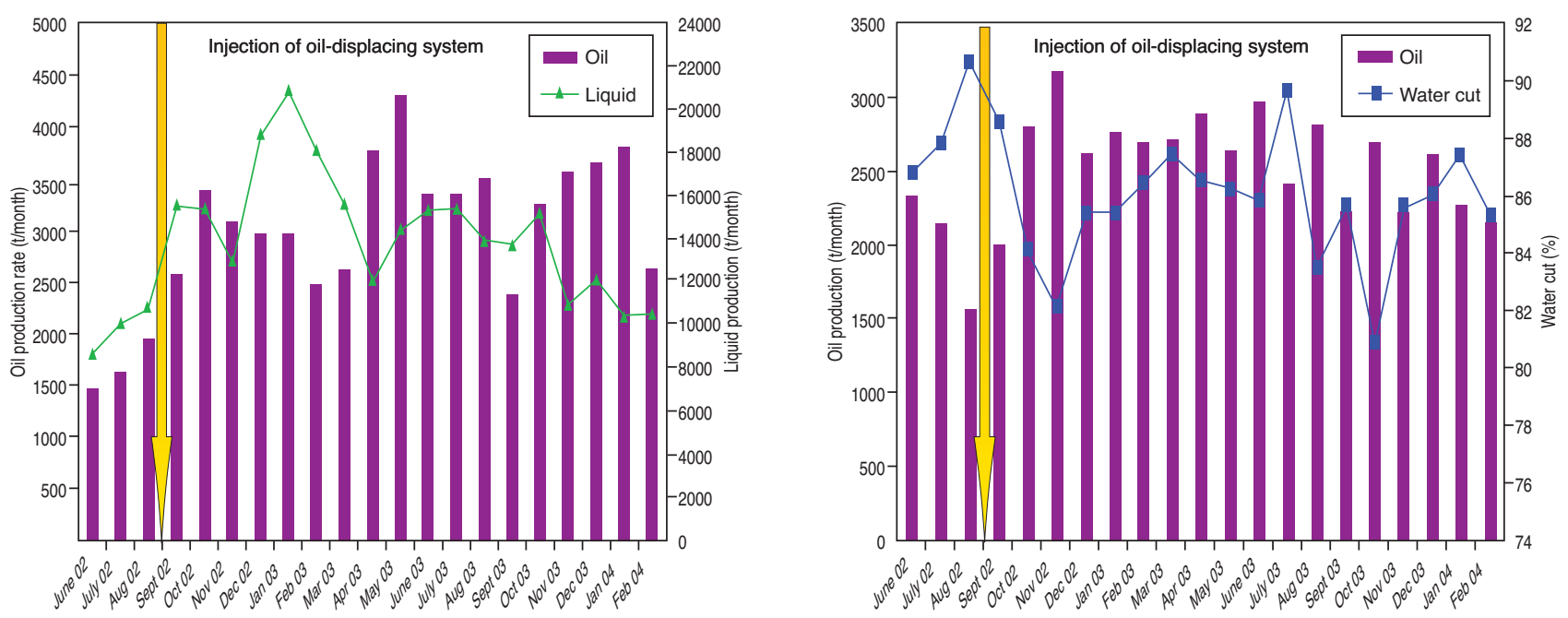

Figure 14

Dynamics of water cut, oil and liquid production rates for the production wells in the test area of a Permocarbonic reservoir in Usinskoye oil field after the injection of the NINKA system into steam-injection wells 4596 and 4040.

(800-1000 $\mathrm{m}^{3} /$ day by water at injection pressure equal to $0)$. During the NINKA system injection the injectivity remained unchanged. The NINKA system proved to have high technological effectiveness and absolute safety under the field conditions. Figure 5 presents the real data for monthly oil and liquid productions and total water cut in the test wells. One can clearly observe the response to the NINKA system injection - an increased oil production rate and decreased water cut. The analysis of the field data indicates that production wells in the test areas start to respond to the NINKA system injection in 1-3 months. The production wells responded as follows: water cut decreased on average by $10-20 \%$; the oil production rate increased by $40 \%$ (Table 1) testifying to the high oil-displacing ability of the NINKA system; and the liquid production rate increased by $5-10 \%$, indicating stimulation of the production (Fig. 14). The fact that for some wells a sharp increase in the oil production rate was accompanied by a considerable increase in the liquid production rate arises from the effective oil-displacing properties of the NINKA system and its ability to decrease oil viscosity in a reservoir by 1.5-6 times. From September 2002 until February 2004 we recovered in addition 44.3 thousand tons of oil in three test areas (Table 1) or 14.7 thousand tons of extra recovered oil per 1 well treatment. IOR technology is recommended for application in oil fields developed by thermal-steam stimulation to treat high-viscosity oil pools.
TABLE 1

Calculation of extra oil production from October 2002 to February 2004 in the test areas after NINKA system injection

\begin{tabular}{c|c|c|c}
\hline $\begin{array}{c}\text { Injection } \\
\text { well }\end{array}$ & Object & $\begin{array}{c}\text { Extra oil recovery, } \\
\text { thou. } t\end{array}$ & $\begin{array}{c}\text { Increase in average monthly } \\
\text { production rate of prod. well, \% }\end{array}$ \\
\hline 4029 & lower & 11.2 & 31 \\
\hline 4040 & lower & 14.0 & 41 \\
\hline 4596 & upper & 19.1 & 49 \\
\hline \multicolumn{2}{c|}{ Total } & 44.3 & On average by $40 \%$ \\
\hline
\end{tabular}

Combined application of gel-forming and oil-displacing systems is promising for high-viscosity oil pools developed by thermal-steam stimulation. As a result, it is possible to increase both conformance and the oil displacement factor in simultaneous intensification of the development.

\subsection{Pilot Tests of IOR Technology Alternating Physicochemical and Cyclic-steam Treatment in Liaohe Oil Field, China}

In 2003 pilot tests of IOR technology were successfully carried out in Liaohe oil field (China) to stimulate a highviscosity oil pool via alteration of physicochemical and cyclic-steam treatments using the surfactant-based NINKA system capable of generating $\mathrm{CO}_{2}$ and alkaline buffer solution in situ. 


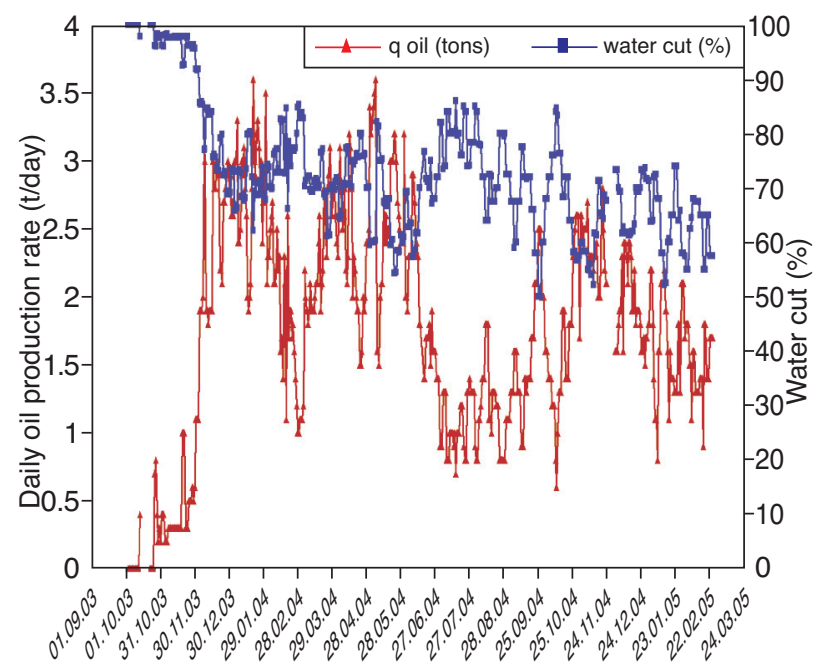

a

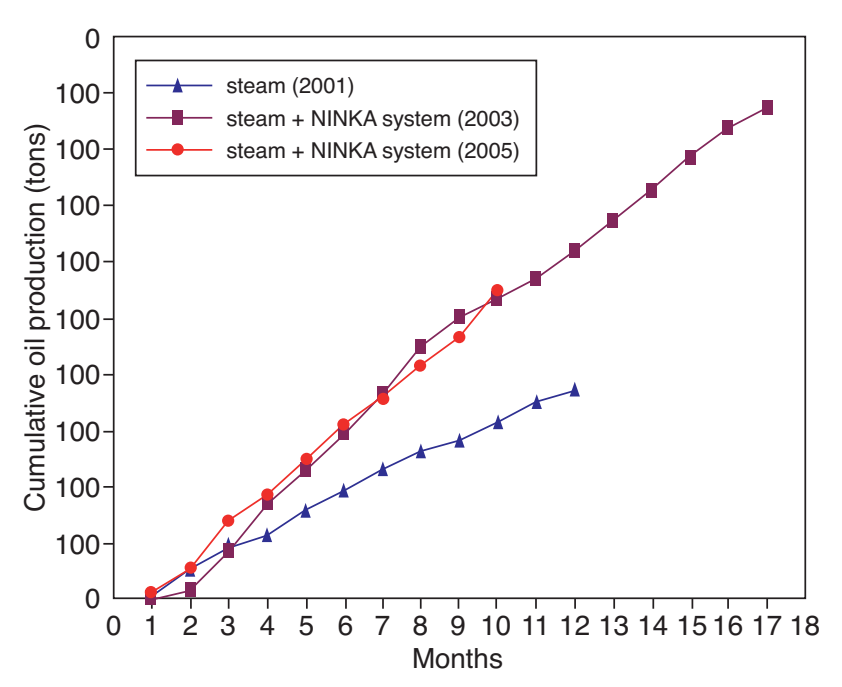

b

Figure 15

Dynamics of: (a) daily oil production and water cut, well Qi 108 3-2 Quanxiling area, Liaohe oil field (China) in the cycle of steam and NINKA system injections; (b) accumulated oil production, well 3-2 in the cycle of steam injection (2001) and in the following cycles of steam and NINKA system injections $(2003,2005)$.

Wells 3-2 and 5-2 are located in the Quanxiling area (Qi 108) in Liaohe oil field. The characteristics of the test are presented in Table 2. A well cluster included 6 wells: 3-2, 3$3,4-2,1-3,4-4$ and 3-4. Well 3-4 was out of operation. Well 4-2 was vertical, while the rest were deviated wells.

We injected 30 and 40 tons of the NINKA system as several slugs into two cyclic-steam wells 3-2 and 5-2, and 2.5 thousand tons of steam into each well. The temperature of the delivered solution of the NINKA system was $45-50^{\circ} \mathrm{C}$. Its density was $1.10-1.12 \mathrm{~g} / \mathrm{cm}^{3}$ at $50-60^{\circ} \mathrm{C}$. The solution was heated up to $60-70^{\circ} \mathrm{C}$ in oil heating apparatus and then was injected into wells by means of an apparatus pump. Heating and injection were carried out uninterruptedly in a flowing regime. The solution was injected at a steam rate of $30-$ $31 \mathrm{~m}^{3} / \mathrm{h}$ and injection pressure was in the range of 1.5-2 MPa.

The data on well 3-2, Quanxiling area, Liaohe oil field, obtained after steam and NINKA system injections are presented in Figure 15. The viscosity of the produced oil decreased by 3 times and the oil congelation point decreased from $+6 \div+10^{\circ} \mathrm{C}$ to $-4 \div-16^{\circ} \mathrm{C}$; the period of oil production was prolonged for 5 months, as compared with the cycle, when the steam was injected.

The data of the pilot tests enable the comparison of the dynamics of cumulative oil recovery from wells Qi 108 3-2 and 5-2 during the cycle of steam injection without the NINKA system and during the following cycle of steam injection with the NINKA system. In cycles of steam injection with the NINKA system the initial period of oil production at high water cut was somewhat longer for each well, as compared with those where only steam was injected. This could be caused by increased coverage with steam treatment by the NINKA system. However, oil production in the cycles of steam injection with the NINKA system was higher than that observed in the cycles of steam injection without the NINKA system. At the same time, after the injection of steam with the NINKA system the cycle duration was several months longer; in other words, the period of oil production was extended. Besides, the viscosity of the produced oil decreased by 3 times and the point of congelation decreased from $6 \div 10^{\circ} \mathrm{C}$ to $-4 \div-16^{\circ} \mathrm{C}$.

TABLE 2

Characteristics of Quanxiling area (Qi 108) in Liaohe oil field

\begin{tabular}{l|c}
\hline Parameter & Parameter Value \\
\hline Oil-producing area, $\mathrm{km}^{2}$ & 4.1 \\
\hline Geological resources, $\mathrm{t}$. & $2157 \times 10^{4}$ \\
\hline Depth, $\mathrm{m}$ & 1000 \\
\hline Spacing between well 3-2 and well 5-3, $\mathrm{m}$ & 175 \\
\hline Initial oil saturation, $\%$ & $51-53$ \\
\hline Clay content, $\%$ & above 13 \\
\hline Initial reservoir pressure, $\mathrm{MPa}$ & 10 \\
\hline Average current pressure in the reservoir, $\mathrm{MPa}$ & 1.75 \\
\hline Reservoir temperature, ${ }^{\circ} \mathrm{C}$ & 45 \\
\hline Thermal gradient,${ }^{\circ} \mathrm{C} / 100 \mathrm{~m}$ & 3.3 \\
\hline
\end{tabular}


From October 2003 until March 2005 oil production from well 3-2 amounted to 874 tons, i.e. 2.3 times higher as compared with the previous cycle, when only steam was injected $(375$ t). From October 2003 until January 2005 oil production from well 5-2 amounted to 1387 tons, while in the previous cycle, when only the steam was injected, it equaled 786 tons; oil production increased by $76 \%$.

In 2005 we continued to employ the NINKA system and injected it into 5 steam-injection wells. At present the wells are kept under observation. It should be noted that in 2005 the NINKA system was reinjected into well 3-2 (Fig. 15b). Oil production in this cycle practically coincides with that in the previous cycle and at the same time it is more effective as compared with steam injection only. Pilot tests, carried out in Liaohe oil field to increase the efficiency of steam-cyclic treatment of a high-viscosity oil pool, proved the efficiency of the oil-displacing NINKA system. The solid marketable form of the NINKA-1 system is commercially manufactured by Liaoyang Oxiranchem Co., Ltd. in Laoning Province of China.

Pilot tests of IOR technology, carried out in oil fields of Russia and China in thermal-steam and cyclic-steam treatments of high-viscosity oil pools, proved the efficiency of IOR technology and its ecological safety.

Thus combined technologies involving physicochemical treatment are considered as an additional reserve for improved oil recovery from high-viscosity oil pools.

\section{CONCLUSIONS}

Novel physicochemical technologies have been developed at the Institute of Petroleum Chemistry SB RAS to improve oil recovery of high-viscosity oil pools, employing gel-forming and oil-displacing systems: gels increase conformance with steam injection, while oil-displacing systems provide additional oil displacement.

IOR technologies have been developed to regulate filtration flows in thermal-steam treatment with thermotropic gelforming systems: polymer systems based on cellulose ether and inorganic systems, i.e. aluminum salt - carbamide - surfactant - water. Under surface conditions thermotropic gelforming systems are low-viscous aqueous solutions, which under reservoir conditions convert into gels. Gelation proceeds due to the heat energy of the injected heat carrier.

The kinetics of gelation, and rheological and filtration properties of gels were studied. Gel-forming systems with different times of gelation - from several minutes to some days - at temperatures ranging from 30 to $320^{\circ} \mathrm{C}$ are proposed. Due to application of gel-forming systems it is possible to create reflecting screens in the reservoir and regulate filtration flows and thereby to improve oil recovery and decrease water cut of well production.

The use of thermotropic inorganic and polymer gels in thermal-steam and cyclic-steam treatments, intended to regu- late filtration flows and to decrease water production in oil fields of Russia and China, increases coverage by steam injection, decreases water cut of well production by $3-45 \%$, increases the oil production rate by $11-33 \%$ and decreases the fluid production rate by $14-25 \%$.

IOR technology has been developed for alternated thermal-steam and physicochemical treatments of high-viscosity oil pools with oil-displacing systems at a later stage of oil field development. The systems contain surfactants and in thermal-steam treatment they are capable of generating carbon dioxide gas and alkaline buffer solutions in situ. As a result, oil viscosity, interfacial tension and clay swelling decrease, whereas the mobility of reservoir fluids increases, which leads to an increased oil-displacement factor and decreased residual oil saturation.

Pilot tests were carried out in Usinskoye oil field in Russia and in Lyaohe oil field in China. Due to stationary injection of steam water cut of well production decreased by $10-20 \%$, whereas the oil production rate increased on average by $40 \%$ and the fluid production rate increased on average by $5-10 \%$. Due to thermal-steam treatment oil production increased 1.82.3 times and the stage of oil production was prolonged by $3-$ 5 months. At the same time, oil viscosity decreased 3 times and freezing point decreased by $10-22^{\circ} \mathrm{C}$.

\section{REFERENCES}

1 Maksutov R., Orlov G., Osipov A. (2005) Development of HighViscosity Oil Reserves in Russia, Tekhnologii TEK 6, 36-40.

2 Burger J., Sourieau P., Combarnous M. (1984) Récupération assistée du pétrole, les méthodes thermiques, Technip, Paris.

3 Greaves M., Xia T.X. (2003) Short-Distance Displacement Pathway for Success for Heavy Oil Recovery and Upgrading, in Progress in Mining and Oilfield Chemistry, Advances in Incremental Petroleum Production, Lakatos I. (ed.), Akademiai Kiado, Budapest, Vol. 5, pp. 79-89.

4 Prats M. (1986) Thermal Recovery, Society of Petroleum Engineers, Monograph 7, 226.

5 Butler R.M. (1991) Thermal Recovery of Oil and Bitumen, Prentice-Hall, Englewood Cliffs, NJ, 1.

6 Surguchev M.L. (1985) Secondary and Tertiary Methods for Enhanced Oil Recovery, Nedra, Moscow.

7 Surguchev M.L., Gorbunov A.T., Zabrodin D.P., Ziskin E.A., Malyutina G.S. (1991) Methods for Residual Oil Recovery, Nedra, Moscow.

8 Altunina L.K., Kuvshinov V.A. (1995) Enhanced Oil Recovery with Surfactant Systems, Nauka, Novosibirsk.

9 Altunina L.K., Kuvshinov V.A. (2001) Physicochemical Aspects of EOR Technologies (review), Khimia $v$ Interesakh Ustoychovogo Razvitiya 9, 331-344.

10 Altunina L.K., Kuvshinov V.A. (2002) The Use of Thermotropic Gels to Enhance Oil Recovery, Nefteotdacha 5, 28-35.

11 Altunina L.K., Bokserman A.A., Kuvshinov V.A., Polkovnikov V.V. (1995) Inorganic Gels to Enhance Oil Recovery of High Temperature Formations, in: New Development in Improved Oil Recover, Geol. Soc. Special Publication 84, 219-223. 
12 Altunina L.K., Kuvshinov V.A. (2003) Pilot Tests in HighViscosity Oil Fields Using Inorganic Gels Generated by Thermal-Steam Treatment, in Progress in Mining and Oilfield Chemistry, Advances in Incremental Petroleum Production, Lakatos I. (ed.), Akademiai Kiado, Budapest, Vol. 5, pp. 115-122.

13 Altunina L.K., Kuvshinov V.A., Stasyeva L.A., Dorokhov V.P., Gusev V.V. (1999) Polymer Solutions with Lower Critical Solution Temperature in EOR Technologies, Neftekhimia 39, 1, 42-47.

14 Altunina L.K., Kuvshinov V.A., Shirgazin R.G. (2004) Water Shutoff Technology Employing Gel-Forming Systems. 66th EAGE Conference \& Exhibition, Paris, France, June 7-10, 2004, CD-ROM, Paper F014.

15 Mohanty S., Khataniar S. (1995) Sodium orthosilicate: an effective additive for alkaline steamflood, J. Petrol. Sci. Eng. $\mathbf{1 4}, 1,2,45-49$.
16 Altunina L.K., Kuvshinov V.A. (2005) Improved ThermalSteam Treatment of High-Viscosity Oil Pools by $\mathrm{CO}_{2}$ Generating Systems. 13th European Symp. Improved Oil Recovery, Budapest, Hungary, April 25-27, 2005, CD-ROM, Paper C12.

17 Altunina L.K., Kuvshinov V.A., Stasyeva L.A. (2003) Rheokinetic Research in the System: High-Viscosity Oil - OilDisplacing Solution Generating $\mathrm{CO}_{2}$ and Alkaline Buffer System in situ. Proc. of the 12th European Symp. "Improved Oil Recovery”, Kazan, September 8-10, CD-ROM, Paper P007.

18 Altunina L.K., Kuvshinov V.A., Stasyeva L.A. (2003) Effect of in situ Generated $\mathrm{CO}_{2}$ and Alkaline Buffers on Rheological Properties of High Viscosity Oils, in Progress in Mining and Oilfield Chemistry, Lakatos I. (ed.), Akademiai Kiado, Budapest, Vol. 5, pp. 123-132.

Final manuscript received in September 2007 work owned by others than IFP must be honored. Abstracting with credit is permitted. To copy otherwise, to republish, to post on servers, or to redistribute to lists, requires prior specific permission and/or a fee: Request permission from Documentation, Institut français du pétrole, fax. +33147527078 , or revueogst@ifp.fr. 